\title{
Role of ceramide in mediating apoptosis of irradiated LNCaP prostate cancer cells
}

\author{
K Kimura ${ }^{1}$, M Markowski $^{1}$, LC Edsall ${ }^{2}$, S Spiegel ${ }^{3}$ \\ and EP Gelmann ${ }^{\star 1,3}$ \\ 1 Department of Oncology, Lombardi Cancer Center, Georgetown University, \\ Washington, DC 20007-2197, USA \\ 2 Department of Biochemistry, Georgetown University Medical Center, \\ Washington, DC 20007-2197, USA \\ ${ }^{3}$ Department of Biochemistry and Molecular Biophysics, Medical College of \\ Virginia Campus, Virginia Commonwealth University, Richmond, VA 23298- \\ 0614, USA \\ * Corresponding author: Gelmann, Department of Oncology, Lombardi Cancer \\ Center, Georgetown University, 3800 Reservoir Road, NW Washington, DC \\ 20007-2197, USA. Tel: +1 202687 2207; Fax: +1 2027841229 \\ E-mail: gelmanne@georgetown.edu
}

Received 17.5.02; revised 30.7.02; accepted 12.8 .02

Edited by ME Peter

\begin{abstract}
The sphingomyelin metabolites ceramide and sphingosine are mediators of cell death induced by $\gamma$-irradiation. We studied the production of ceramide and the effects of exogenous ceramide on apoptosis in LNCaP prostate cancer cells that are highly resistant to $\gamma$-irradiation-induced cell death. LNCaP cells can be sensitized to $\gamma$-irradiation by tumor necrosis factor $\alpha$ (TNF- $\alpha$ ) and, to a lesser degree, by the agonistic FAS antibody CH-11. TNF- $\alpha$ activated intrinsic and extrinsic apoptosis pathways and increased ceramide and sphingosine levels in irradiated LNCaP cells. $\mathrm{CH}-11$ activated only the extrinsic apoptosis pathways and had a negligible effect on ceramide and sphingosine levels in irradiated LNCaP cells. Exogenous ceramide and bacterial sphingomyelinase sensitized LNCaP cells to radiation-induced apoptosis and had a synergistic effect on cell death after irradiation with TNF- $\alpha$, but not with $\mathrm{CH}-11$. Cell death effects after exposure to ceramide and irradiation were blocked by the serine protease inhibitor TLCK (Na-p-tosyl-L-lysinechloromethylketone), but not by the caspase inhibitor z-VAD (2-val-Ala-Asp(oMe)-CH ${ }_{2} \mathrm{~F}$ ). During LNCaP cell apoptosis induced by exogenous ceramide, we observed activation of caspase-9, but not caspases-8, -3 , or -7 . The effect of ceramide occurred largely via the intrinsic mitochondrial apoptosis pathway and enhanced TNF- $\alpha$, but not $\mathrm{CH}-11$ effects on irradiated cells. The data show that ceramide enhanced activation of the intrinsic apoptotic pathway and enhanced cell death induced by TNF- $\alpha$ with or without $\gamma$ irradiation. TNF- $\alpha$ and $\gamma$-irradiation elevated levels of endogenous ceramide and activated the intrinsic cell death pathway.

Cell Death and Differentiation (2003) 10, 240-248. doi:10.1038/ s..cdd. 4401145
\end{abstract}

Keywords: TNF- $\alpha$; ceramide; caspase; serine protease; prostate cancer; radiation

\begin{abstract}
Abbreviations: NF- $\kappa \mathrm{B}$, nuclear factor $\kappa \mathrm{B}$; $\mid \kappa \mathrm{B} \alpha$, inhibitor of nuclear factor $\kappa \alpha$; I $\kappa \mathrm{BSR}$, I $\kappa \mathrm{B} \alpha$ super repressor; TNF- $\alpha$, tumor necrosis factor $\alpha$; z-VAD, z-Val-Ala-Asp $(\mathrm{OMe})-\mathrm{CH}_{2} \mathrm{~F}$; TLCK, Na-p-tosyl-L-lysine-chloromethylketone; AAD, z-Ala-Ala-As$\mathrm{p}(\mathrm{OMe})-\mathrm{CH}_{2} \mathrm{~F}$; AAPD-pNa, $\mathrm{N}$-succinyl-Ala-Ala-Pro-Asp-p-nitroanilide; IETD, z-lle-Glu-Thr-Asp(OMe)- $\mathrm{CH}_{2} \mathrm{~F}$; LEHD, $\mathrm{N}$ acetyl-Leu-Glu-His-Asp-CHO; FADD, FAS-associated death domain; FADD-DN, dominant negative mutant of FADD; DISC, death-inducing signaling complex
\end{abstract}

\section{Introduction}

Activation of apoptosis by ligand binding to cell surface death receptors such as FAS or tumor necrosis factor $\alpha$ (TNF- $\alpha$ ) results in the formation of the death-inducing signaling complex (DISC), which includes the cytoplasmic domain of the death receptor, Fas-associated death domain (FADD), caspase-8, and other adaptor proteins. ${ }^{1,2}$ Subsequent to formation of the DISC, caspase-8 is cleaved to initiate the proteolytic cascade that leads to apoptosis. FAS activation triggers a cascade termed the extrinsic pathway, which includes caspases-8 and -3 , eventually cleaving Poly ADP Ribose Polymerase (PARP) and the inhibitor of DNA Fragmentation Factor (DFF), a DNase that generates nucleosomal DNA fragments that can be detected as DNA laddering. ${ }^{2-8}$ TNF- $\alpha$ initiates a more complex set of signaling events that can include activation of the extrinsic cell death pathway. ${ }^{9,10}$ TNF- $\alpha$ activation also triggers a separate antiapoptotic pathway via activation of nuclear factor $\kappa \mathrm{B}$ $(\mathrm{NF}-\kappa \mathrm{B})$ that probably explains the stimulation rather than execution of inflammatory cells by TNF- $\alpha .{ }^{11-14}$

Induction of cell death by cellular injury or loss of survival signals is mediated predominantly by pathways that are intrinsic and can be triggered by a variety of stimuli leading to egress of cytochrome $c$ from the mitochondria, activation of caspase- 9 and subsequent death execution. ${ }^{15,16}$ The intrinsic and extrinsic pathways connect through a variety of mechanisms. For example, caspase- 8 activation by death ligands can result in cleavage of BID that can complex with the antiapoptotic protein $\mathrm{BAX}$, leading to mitochondrial egress of cytochrome $c$ and activation of caspase-9. ${ }^{17-21}$ Various insults to the cell can cause increased expression of FAS and/ or FAS ligand resulting in activation of caspase- 8 and its downstream targets. ${ }^{22-25}$ In addition to activation of FASmediated signaling, apoptotic stimuli induce cells to produce other endogenous mediators of cell death such as the sphingolipid metabolite ceramide. ${ }^{26,27}$ In response to cell stress such as ionizing radiation, ceramide is produced by activation of either sphingomyelinases or ceramide synthases. ${ }^{28-30}$ Ceramide production is not a universal 
phenomenon and appears to have a proapoptotic role in certain cell types. ${ }^{30,31}$ Cellular levels of both ceramide and its metabolite sphingosine, are increased after exposure of LNCaP prostate cancer cells to TNF- $\alpha$ and irradiation. We have shown that LNCaP prostate cancer cells are highly resistant to radiation-induced apoptosis. However, irradiation sensitizes LNCaP cells to apoptosis induction by either TNF- $\alpha$ or FAS. ${ }^{32,33}$

Here we confirm that ceramide production in irradiated LNCaP cells is induced by TNF- $\alpha$ and show that the FAS agonist, antibody $\mathrm{CH}-11$, does not cause ceramide production during the execution of cell death. Addition of exogenous $\mathrm{C}_{2}-$ ceramide or bacterial sphingomyelinase enhances cell death induced by TNF- $\alpha$, but has no effect on cell death induced by $\mathrm{CH}-11$ in the absence or presence of irradiation. This implies that an activation threshold exists for the proapoptotic effects of ceramide on LNCaP cells and that these cells can respond to ceramide only under some conditions of apoptosis induction. Those proapoptotic effects lead to mitochondrial depolarization, the activation of serine proteases, and caspase- 9 activation.

\section{Results}

\section{Production of sphingomyelin metabolites after treatment of LNCaP cells with death ligands}

LNCaP prostate cancer cells are highly resistant to apoptosis induced by $\gamma$-irradiation. ${ }^{32,34}$ Both TNF- $\alpha$ and the agonistic FAS antibody $\mathrm{CH}-11$ sensitize $\mathrm{LNCaP}$ cells to irradiationinduced apoptosis. ${ }^{32}$ TNF- $\alpha$ plus irradiation increased levels of sphingosine and ceramide, ${ }^{32,35}$ but $\mathrm{CH}-11$ alone or with irradiation had no effect on either sphingosine or ceramide content (Figure 1). TNF- $\alpha$ and irradiation activate both the death-ligand-dependent extrinsic and the mitochondriamediated intrinsic apoptosis pathways. In LNCaP and other cell lines, the intrinsic cell death pathway leads to activation of both caspases and serine proteases, which in the case of LNCaP cells cause about $50 \%$ apoptosis. ${ }^{32}$ In contrast, $\mathrm{CH}$ 11 plus irradiation induces cell death predominantly via the extrinsic apoptosis signaling pathway. ${ }^{32,33}$ We next sought to determine the role of ceramide in mediating LNCaP cell death.

\section{Effect of ceramide on LNCaP cell death}

Exogenous $\mathrm{C}_{2}$-ceramide induces a low level of apoptosis in LNCaP cells that sensitizes the cells to $\gamma$-irradiation. ${ }^{32}$ As can be seen in Figure $2 a$, the pancaspase inhibitor z-VAD (z-ValAla-Asp $(\mathrm{OMe})-\mathrm{CH}_{2} \mathrm{~F}$ ) had no effect on $\mathrm{C}_{2}$-ceramide-induced cell death. Exposure to higher doses of z-VAD inhibited cell death induced by $\mathrm{C}_{2}$-ceramide alone, but not by $\mathrm{C}_{2}$-ceramide together with irradiation (Figure $2 b$ ). On the other hand, the serine protease inhibitor TLCK (Na-p-tosyl-L-lysine-chloromethylketone) inhibited induction of LNCaP cell death after exposure to $\mathrm{C}_{2}$-ceramide and irradiation (Figure $2 \mathrm{c}$ ). We characterized caspase activation in $\mathrm{LNCaP}$ cells after exposure to $\mathrm{C}_{2}$-ceramide and irradiation. As can be seen on the left side of Figure $3, \mathrm{C}_{2}$-ceramide and irradiation induce a low level of caspase- 9 activation, but not caspases- 8 or -7 activation, suggesting that ceramide activated the intrinsic cell
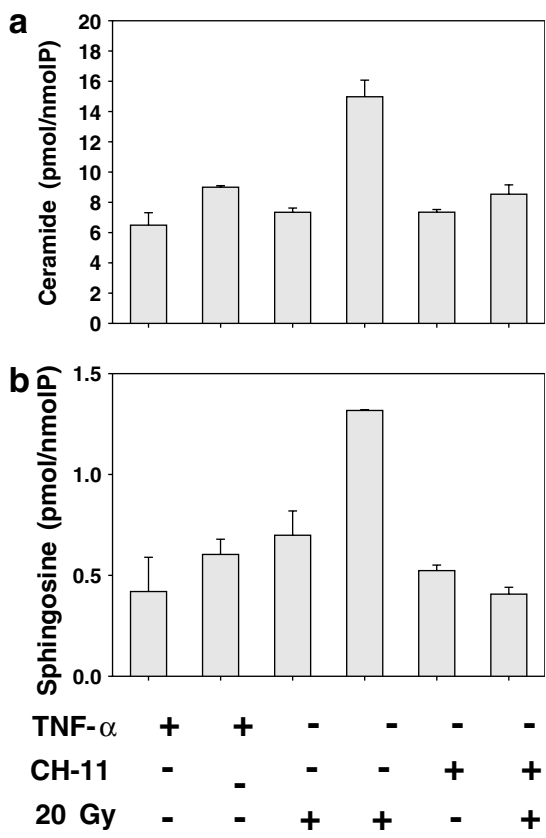

Figure 1 (a) Ceramide and (b) sphingosine content in LNCaP cells $48 \mathrm{~h}$ after treatment with $40 \mathrm{ng} / \mathrm{ml} \mathrm{TNF}-\alpha, 1 \mu \mathrm{g} / \mathrm{ml} \mathrm{CH}-11$, and/or $20 \mathrm{~Gy}$ irradiation as indicated. The data are a mean of three determinations and were normalized for the amount of lipid phosphate in the samples. Standard deviations are shown

death pathway. The serine protease inhibitor TLCK inhibited caspase- 9 activation after exposure of LNCaP cells to $\mathrm{C}_{2}$ ceramide plus irradiation, suggesting that the effect of $\mathrm{C}_{2}$ ceramide on cell death is mediated via serine protease activation that is upstream of caspase- 9 activation (Figure 3 ).

\section{$\mathrm{C}_{2}$-ceramide potentiates TNF- $\alpha$-mediated more than $\mathrm{CH}-11$-mediated apoptosis}

Since $\mathrm{C}_{2}$-ceramide predominantly activated the intrinsic cell death pathway, we determined whether it could enhance cell death induced by activation of death receptors. A significant effect of $\mathrm{C}_{2}$-ceramide could be seen in irradiated cells treated with either $\mathrm{CH}-11$ or TNF- $\alpha$. At $24 \mathrm{~h}$ after exposure, a time when there is little to no cell death in LNCaP cells treated with either TNF- $\alpha$ or $\mathrm{CH}-11, \mathrm{C}_{2}$-ceramide in combination with $\mathrm{CH}$ 11 resulted in more than $30 \%$ cell death and in combination with TNF- $\alpha$, more than $90 \%$ cell death (Figure $4 \mathrm{a}$ ). These results suggest that $\mathrm{C}_{2}$-ceramide had a more profound effect on the intrinsic pathway in TNF- $\alpha$-treated cells, perhaps because TNF- $\alpha$ also activated the intrinsic pathway and affected endogenous ceramide production and ceramide responsiveness, whereas $\mathrm{CH}-11$ did not. Expression of dominant negative mutant of FADD (FADD-DN) completely blocked apoptosis after exposure to $\mathrm{C}_{2}$-ceramide with or without TNF- $\alpha, \mathrm{CH}-11$ and irradiation. The protective effect of FADD-DN on ceramide-mediated cell death was similar to the effects seen with cells exposed to TNF- $\alpha$ or TNF- $\alpha$ with irradiation. ${ }^{33}$ FADD-DN expression was used as a way to block the extrinsic cell death pathway in order to demonstrated that FADD activation and the extrinsic pathway were 

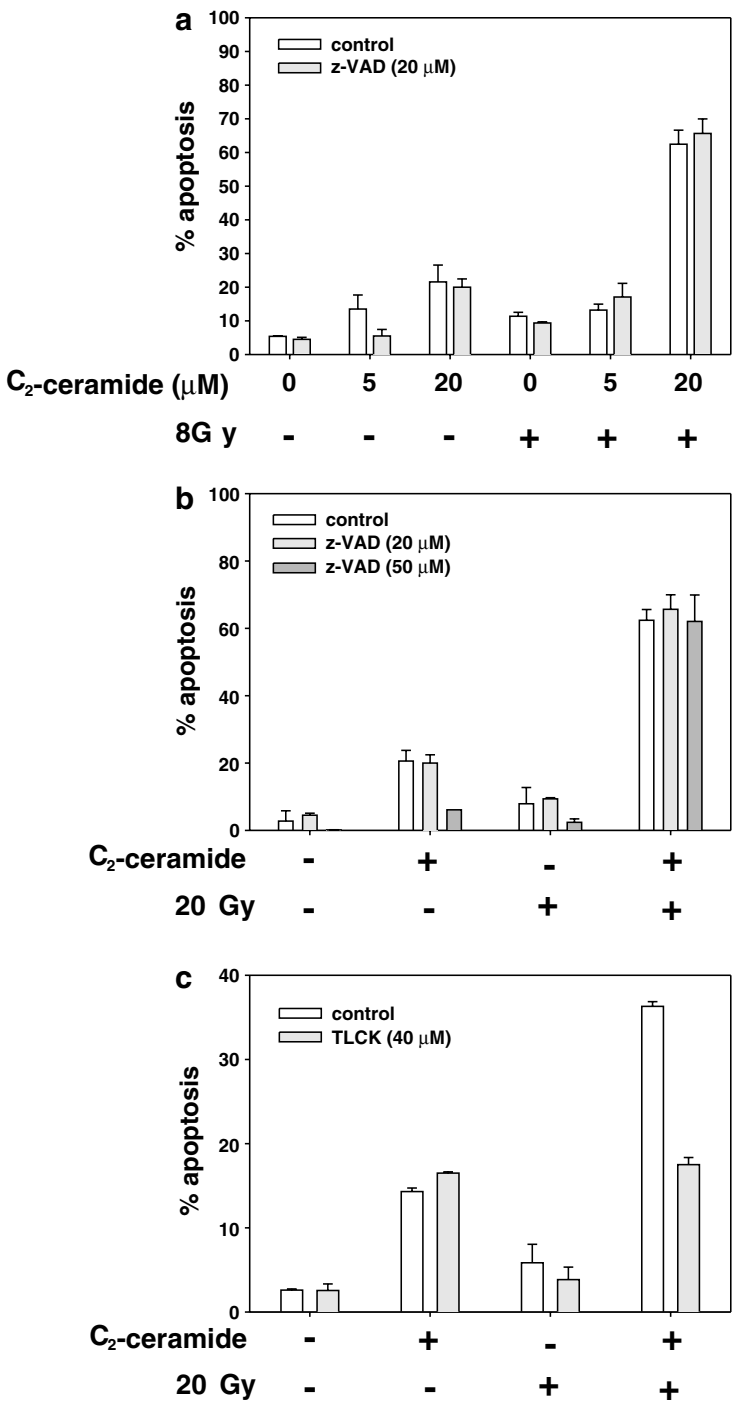

Figure 2 Effect of either z-VAD or TLCK on apoptosis induced by $\mathrm{C}_{2}$-ceramide and 8 or 20 Gy irradiation $72 \mathrm{~h}$ after treatment. The concentration of $\mathrm{C}_{2}$-ceramide in $\mathbf{b}$ and $\mathbf{c}$ was $20 \mu \mathrm{M}$. Results are the mean of triplicate cultures analyzed separately

critical for the proapoptotic effects of $\mathrm{C}_{2}$-ceramide in $\mathrm{LNCaP}$ cells. Expression of FADD-DN also blocked the effects of TNF- $\alpha$ in the absence or presence of irradiation on ceramide and sphingosine content (data not shown). Since $\mathrm{C}_{2}$ ceramide has a shorter hydrocarbon chain than endogenously generated ceramides, we repeated the experiments in LNCaP cells using bacterial sphingomyelinase to increase levels of endogenous ceramide and found nearly identical results as with exogenous $\mathrm{C}_{2}$-ceramide (Figure $4 \mathrm{~b}$ ).

\section{Activation of apoptotic proteases by $\mathrm{C}_{2}$-ceramide}

Because of the different degrees to which $\mathrm{C}_{2}$-ceramide enhanced apoptosis induced by $\mathrm{CH}-11$ or TNF- $\alpha$, we examined the activation of caspases and other proapoptotic proteins in LNCaP cells (Figure 5). Caspase-8 cleavage was induced by death ligand treatment with or without irradiation in

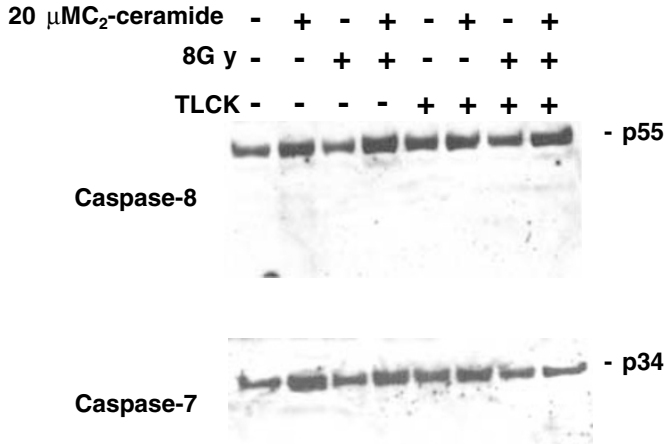

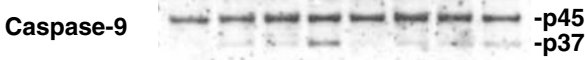

Figure 3 Western blotting for caspases-7, -8 , and 9 in LNCaP cells treated with $\mathrm{C}_{2}$-ceramide and $8 \mathrm{~Gy}$ irradiation either in the absence or presence of $40 \mu \mathrm{M}$ TLCK at $72 \mathrm{~h}$ after treatment. The molecular weights of precursor and cleaved proteins are designated on the right side of the blots

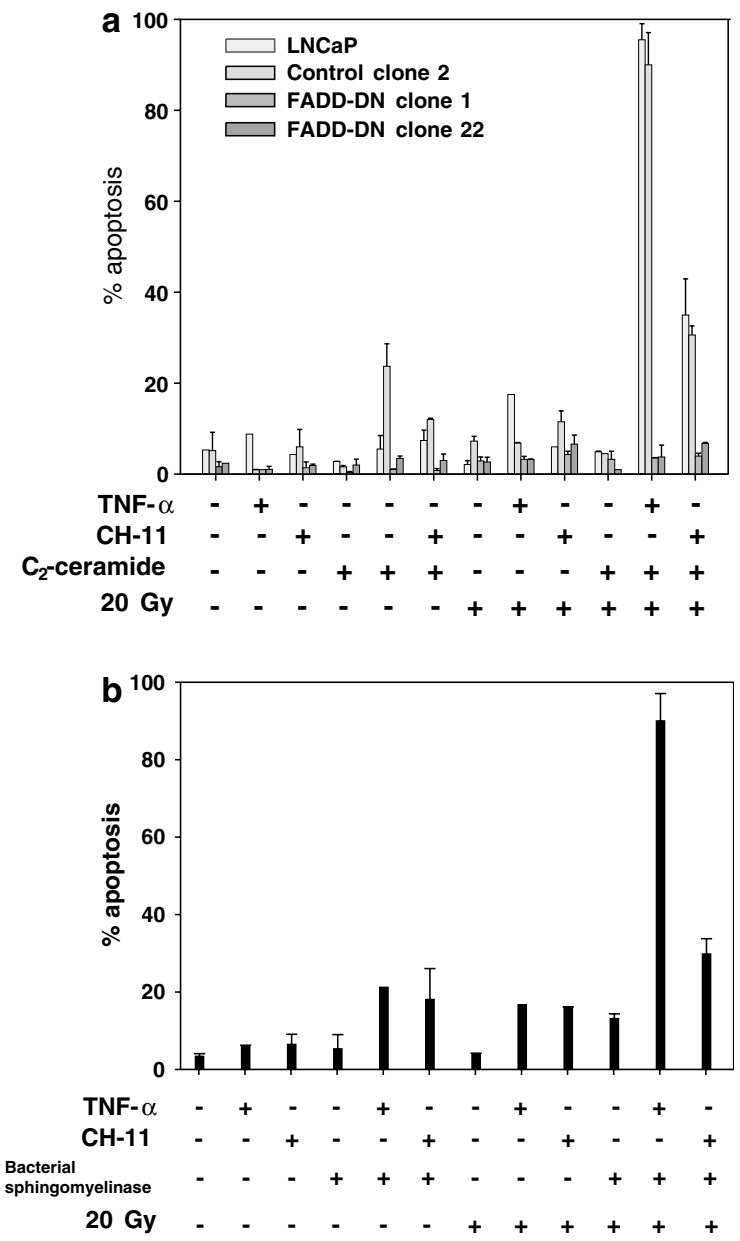

Figure 4 (a) Apoptosis $24 \mathrm{~h}$ after treatment of $\mathrm{LNCaP}$ cells, LNCaP cells stably transfected with control vector, and LNCaP cells stably transfected with FADDdominant negative vector with $40 \mathrm{ng} / \mathrm{ml} \mathrm{TNF}-\alpha, 1 \mu \mathrm{g} / \mathrm{ml} \mathrm{CH}-11,20$ Gy irradiation, and $20 \mu \mathrm{M} \mathrm{C}_{2}$-ceramide at (b) Apoptosis in $\mathrm{LNCaP}$ cells $24 \mathrm{~h}$ after treatment with $40 \mathrm{ng} / \mathrm{ml} \mathrm{TNF}-\alpha, 1 \mu \mathrm{g} / \mathrm{ml} \mathrm{CH}-11,20 \mathrm{~Gy}$ irradiation, and $300 \mathrm{mU} / \mathrm{ml}$ bacterial sphingomyelinase as indicated 

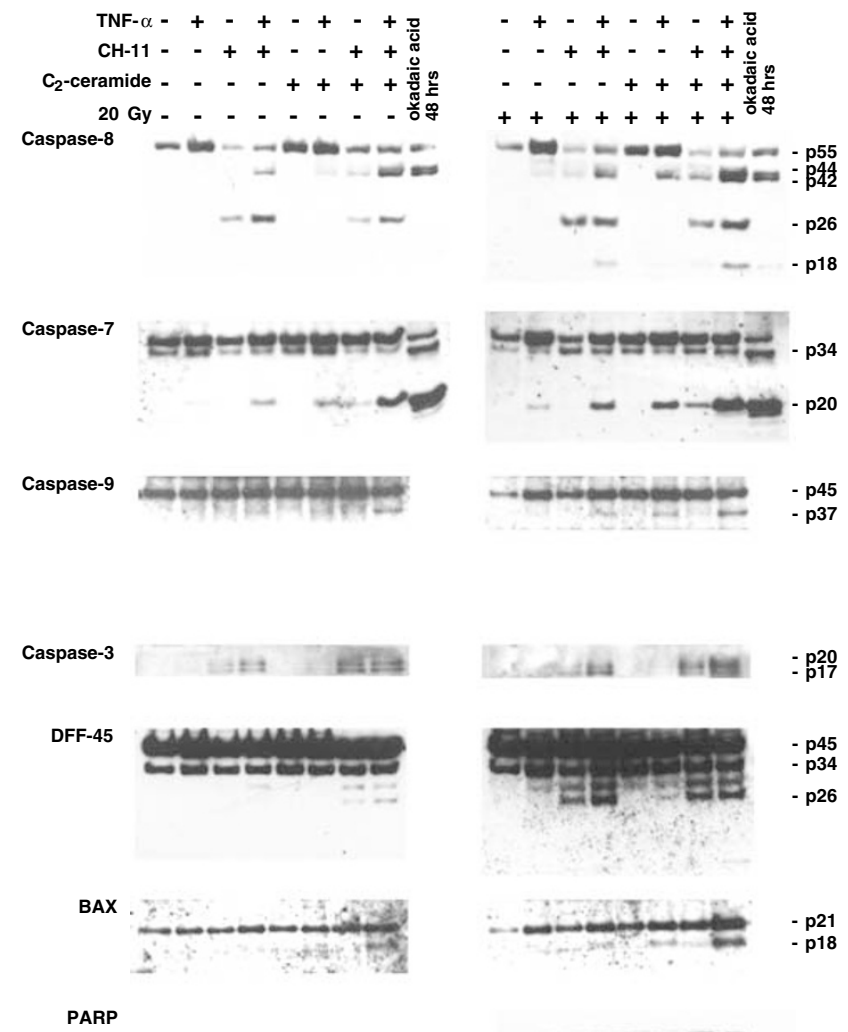

PAR

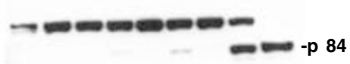

Figure 5 Western blotting for caspases, DFF-45, BAX, and PARP in LNCaP cells treated with TNF- $\alpha, \mathrm{CH}-11, \mathrm{C}_{2}$-ceramide, and radiation $24 \mathrm{~h}$ after treatment. The molecular weights of precursor and cleaved proteins are designated on the right side of blots. Extracts from LNCaP cells treated with $30 \mathrm{nM}$ okadaic acid for $48 \mathrm{~h}$ were analyzed for caspases-8, -7 and PARP as positive controls

agreement with previous studies. ${ }^{33} \quad \mathrm{C}_{2}$-ceramide had a minimal effect on caspase- 8 activation in the presence of TNF- $\alpha$ or TNF- $\alpha$ with $\mathrm{CH}-11$, with or without irradiation. Similarly, cleavage of caspase-3 and DFF-45, both downstream of caspase-8, ${ }^{36-39}$ were minimally affected by the presence of $\mathrm{C}_{2}$-ceramide. In contrast, the effect of $\mathrm{C}_{2}$ ceramide was much more pronounced on activation of caspases-7 and -9. Caspase-9 cleavage was observed in cells treated with TNF- $\alpha$, but not with $\mathrm{CH}-11$. Radiation enhanced caspase- 9 cleavage induced by TNF- $\alpha . \quad C_{2}-$ ceramide alone had no detectable effect on caspase- 9 at $24 \mathrm{~h}$ after treatment. However, $\mathrm{C}_{2}$-ceramide markedly enhanced caspase- 9 cleavage induced by TNF- $\alpha$ in the presence or absence of irradiation. $\mathrm{CH}-11$ did not activate caspase- 9 cleavage alone or in the presence of $\mathrm{C}_{2}$-ceramide.

Although $\mathrm{CH}-11$ did not induce detectable caspase-7 cleavage at $24 \mathrm{~h}$ after treatment, in the presence of $\mathrm{C}_{2}$ ceramide, there was significant caspase- 7 activation. TNF- $\alpha$ treatment induced greater caspase-7 activation than $\mathrm{CH}-11$. Irradiation enhanced caspase-7 cleavage under all circumstances except after exposure to $\mathrm{CH}-11$ alone or $\mathrm{C}_{2}$-ceramide alone. Interestingly, despite the activation of caspase- 3 in LNCaP cells treated with $\mathrm{CH}-11$, PARP cleavage was not evident. In irradiated LNCaP cells, PARP cleavage paralleled caspase-7 activation, consistent with reports that caspase-7 is the predominant effector caspase in LNCaP cells. ${ }^{33,34,40}$ We note that the proapoptotic protein BAX was also cleaved concomitantly with caspase-7 activation.

Taken together with the data in Figures 2 and 3, these results imply that $\mathrm{C}_{2}$-ceramide activated the intrinsic cell death pathway mediated by casapses- 9 and -7 downstream of serine protease activation. TNF- $\alpha$ had a greater effect on the intrinsic pathway mediated by caspases-8, -9 , and -7 and $\mathrm{BAX}$, while $\mathrm{CH}-11$ affected the extrinsic pathway including caspases-8, -3 , and DFF-45. $\mathrm{C}_{2}$-ceramide, which activated the intrinsic pathway, potentiated the effects of TNF- $\alpha$ more than those of $\mathrm{CH}-11$.

The role of caspase- 9 in cell death enhancement by $\mathrm{C}_{2}$ ceramide was studied using the caspase- 9 inhibitor LEHD (Nacetyl-Leu-Glu-His-Asp-Cuo) that had no effect on LNCaP cell death induced by $\mathrm{CH}-11$ in the absence or presence of irradiation. In contrast, z-VAD completely blocked $\mathrm{CH}-11$ induced apoptosis (Figure 6a). This result is consistent with the observation that caspase- 9 was not activated by $\mathrm{CH}-11$ in the absence or presence of irradiation. LEHD partially inhibited apoptosis induced by TNF- $\alpha$ and irradiation. The failure of LEHD to block apoptosis completely was likely because of the activation of serine proteases by TNF- $\alpha$ with irradiation, as we have shown previously. ${ }^{32}$ To confirm the presence of activated serine proteases, we used the granzyme and serine protease inhibitor AAD (2-Ala-As$\left.\mathrm{p}(\mathrm{OMe})-\mathrm{CH}_{2} \mathrm{~F}\right)$. Combined treatment with $\mathrm{AAD}$ and LEHD blocked LNCaP cell death completely (Figure 6b). Collectively, these results imply that serine protease activation occurred upstream from mitochondrial activation and was able to mediate some degree of cell death, even in the presence of LEHD. In contrast, LNCaP cell death after simultaneous treatment with $\mathrm{CH}-11$ and TNF- $\alpha$ in the absence or presence of irradiation, occurs within $24 \mathrm{~h}$ and requires only caspase activation. ${ }^{33}$ Under these conditions, either the caspase-8 inhibitor IETD (z-Ile-Glu-Thr-Asp(OMe)- $\mathrm{CH}_{2} \mathrm{~F}$ ) or the caspase- 9 inhibitor LEHD were equally effective at inhibiting cell death, indicating that activation of caspase- 9 via upstream caspase- 8 is the predominant proteolytic cell death program (Figure 6c).

\section{Attenuation of the intrinsic pathway interferes with the effect of ceramide}

Stable expression of $\mathrm{I}_{\kappa} \mathrm{BSR}$, a constitutively active inhibitor of $\mathrm{NF}-\kappa \mathrm{B}$, in $\mathrm{LNCaP}$ cells results in inhibition of apoptosis induced by TNF- $\alpha$ in the presence or absence of irradiation. I $\kappa$ BSR expression inhibits $\mathrm{NF}-\kappa \mathrm{B}$ activity and results in blockade of serine protease activation, an event upstream of mitochondrial activation in the intrinsic cell death pathway. ${ }^{25}$ We used LNCaP cells stably transfected with $\mid \kappa$ BSR because these cells have a strong block of the intrinsic apoptosis pathway. I $\kappa$ BSR expression in LNCaP cells also blocked the increase in ceramide levels after cells were exposed to TNF- $\alpha$ and irradiation, suggesting that NF- $\kappa$ B activity was necessary for the response to irradiation (Figure 7a). ${ }^{32,41,42}$ Increasing ceramide levels by treating $\mathrm{LNCaP}\left(I_{\kappa} \mathrm{BSR}\right)$ cells with bacterial sphingomyelinase was still able to activate cell death, but to a 

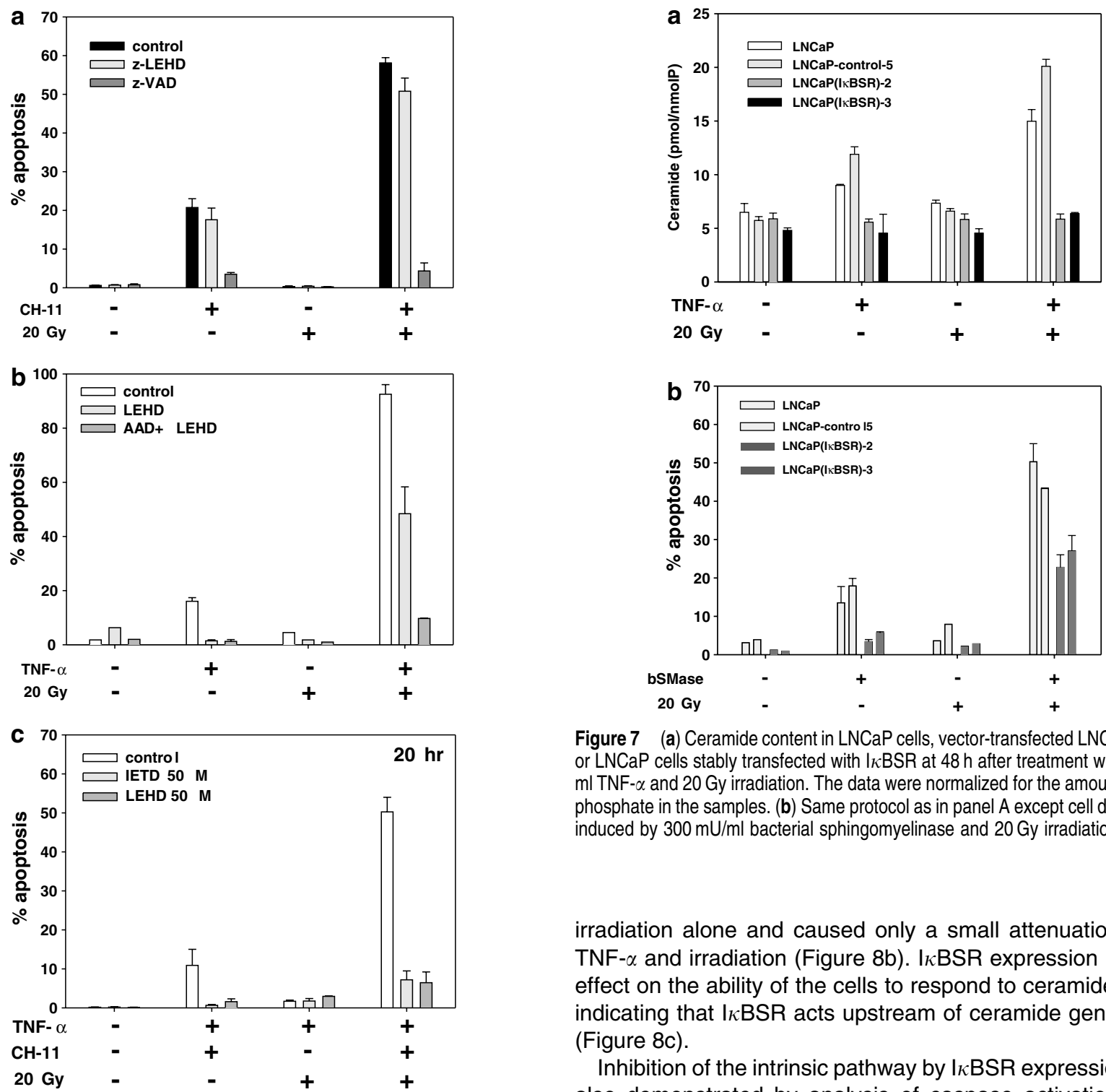

Figure 6 Effect of caspase inhibitors and the granzyme inhibitor z-AAD on apoptosis induced by $40 \mathrm{ng} / \mathrm{ml} \mathrm{TNF}-\alpha, 1 \mu \mathrm{g} / \mathrm{ml} \mathrm{CH}-11$, and $20 \mathrm{~Gy}$ irradiation at either $72 \mathrm{~h}(\mathbf{a}$ and $\mathbf{b})$ or $20 \mathrm{~h}(\mathbf{c})$ after treatment

lesser degree than in parental cells, probably because of the I $\kappa$ BSR inhibition of serine protease activation (Figure $7 \mathrm{~b}$ ). ${ }^{25}$ Interruption of the intrinsic apoptosis pathway in LNCa$\mathrm{P}\left(\mathrm{I}_{\kappa} \mathrm{BSR}\right)$ cells was further elucidated by analysis of mitochondrial membrane depolarization $\left(\Delta \Psi_{\mathrm{m}}\right)$. Increased $\Delta \Psi_{\mathrm{m}}$ is a sensitive indicator of $\mathrm{LNCaP}$ cell exposure to apoptotic stimuli. ${ }^{34}$ In fact, 20 Gy irradiation alone, that otherwise has no measurable effect on induction of apoptosis, increased $\Delta \Psi_{\mathrm{m}}$ in LNCaP cells (Figure 8a). More importantly, expression of I $\kappa$ BSR abrogated all increases in $\Delta \Psi_{\mathrm{m}}$ after exposure of $\mathrm{LNCaP}$ cells to irradiation and/or TNF- $\alpha$. Expression of FADD$\mathrm{DN}$ also blocked the effect of TNF- $\alpha$ alone on the change in $\Delta \Psi_{\mathrm{m}}$, but had no effect on the response to $20 \mathrm{~Gy}$ irradiation (Figure 8a). Inhibition of caspase-8 with IETD also markedly reduced the effect of TNF- $\alpha$ on $\Delta \Psi_{\mathrm{m}}$, but had no effect on

irradiation alone and caused only a small attenuation after TNF- $\alpha$ and irradiation (Figure $8 b$ ). I $\kappa$ BSR expression had no effect on the ability of the cells to respond to ceramide itself, indicating that $\mathrm{I}_{k} \mathrm{BSR}$ acts upstream of ceramide generation (Figure 8c).

Inhibition of the intrinsic pathway by $I_{\kappa} \mathrm{BSR}$ expression was also demonstrated by analysis of caspase activation after cells were treated with TNF- $\alpha$ in the absence or presence of 20 Gy. These treatments attenuated the cell death response of LNCaP cells expressing I $k$ BSR ${ }^{25}$ Caspase- 3 was activated during induction of apoptosis, even to a higher degree than in control cells (Figure 9). However, activation of caspases- 9 and -7 were blocked by I $\kappa$ BSR expression.

\section{Discussion}

Our results show that in $\mathrm{LNCaP}$ prostate adenocarcinoma cells, TNF- $\alpha$ and FAS have different effects on ceramide production. $\mathrm{C}_{2}$-ceramide or bacterial sphingomyelinase augment the effects of endogenous ceramide in LNCaP cells treated with TNF- $\alpha$ and irradiation, but not $\mathrm{CH}-11$ together with irradiation. This implies that TNF- $\alpha$ not only increased ceramide levels, but also triggered a ceramide-responsive state that was not activated by $\mathrm{CH}-11$ in $\mathrm{LNCaP}$ cells. This interpretation is consistent with findings in other cell systems that sphingomyelinase activation is dependent on cas- 

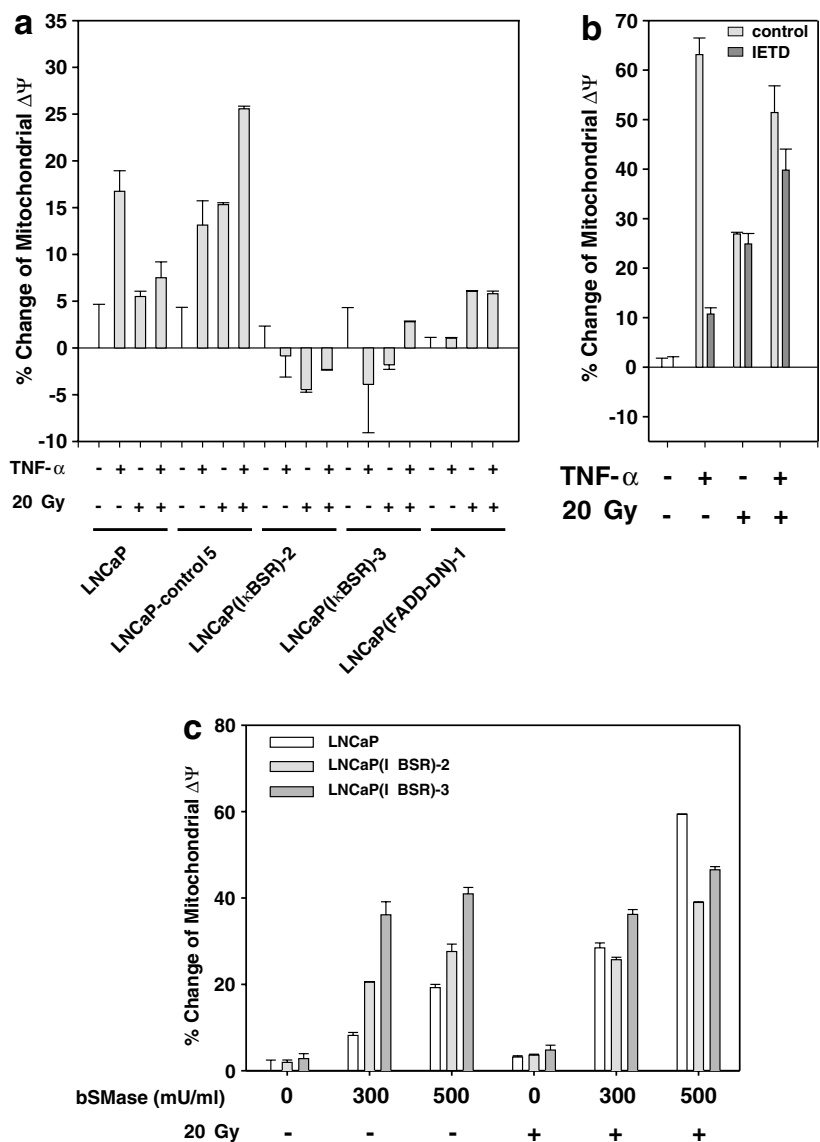

Figure 8 (a) percent change of mitochondrial $\Delta \Psi_{\mathrm{m}}$ in parental and transfected LNCaP cells $24 \mathrm{~h}$ after treatment with $40 \mathrm{ng} / \mathrm{ml}$ TNF- $\alpha$ and 20 Gy irradiation. (b) Effect of $50 \mu \mathrm{M} z$-IETD on the percent change of mitochondrial $\Delta \Psi_{\mathrm{m}}$ in $\mathrm{LNCaP}$ cells at $24 \mathrm{~h}$ after treatment with $40 \mathrm{ng} / \mathrm{ml}$ TNF- $\alpha$ and $20 \mathrm{~Gy}$ irradiation. (c) Percent change of mitochondrial $\Delta \Psi_{\mathrm{m}}$ in parental and transfected $\mathrm{LNCaP}$ cells $18 \mathrm{~h}$ after treatment with $300 \mathrm{mU} / \mathrm{ml}$ bacterial sphingomyelinase and $20 \mathrm{~Gy}$ irradiation

pases. ${ }^{43-45}$ In irradiated LNCaP cells, $\mathrm{CH}-11$ did not activate the intrinsic death pathway or sufficiently increase cellular ceramide or sphingosine. In contrast, TNF- $\alpha$ activated both the intrinsic pathway and ceramide production. Irradiation of $\mathrm{LNCaP}$ cells had no effect on ceramide production. We propose that in LNCaP cells, increased ceramide activates a secondary death pathway that amplifies a cell death signal and follows caspase activation.

We observed that the effects of ceramide were mediated by serine proteases, inhibitable by TLCK and AAD and manifested by mitochondrial membrane depolarization and caspase- 9 activation. The addition of short-chain ceramides to isolated mitochondria or to cell cultures has been reported to induce direct inhibition of complex III of the mitochondrial respiratory chain, the generation of reactive oxygen species, cytochrome $c$ release and a decrease in transmembrane potential. ${ }^{46,47}$ The effects of short-chain ceramides can also be blocked by $\mathrm{Bcl}-2 .{ }^{48}$ Therefore, it is likely that ceramide responsiveness is mediated through a mitochondria-dependent death pathway. Exogenous ceramide has also been shown to promote capping of FAS on the cell surface, thereby

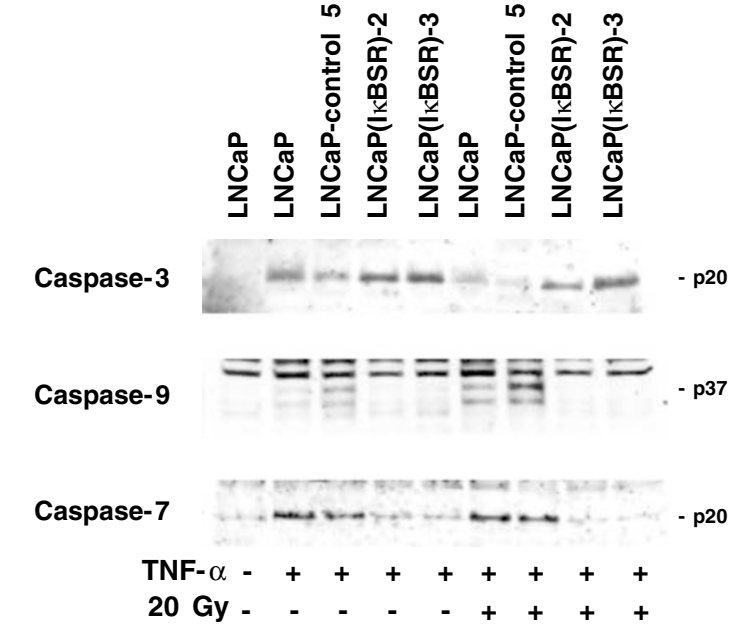

Figure 9 Western blotting for caspases-3, -7 , and -9 in parental and transfected $\mathrm{LNCaP}$ cells either $24 \mathrm{~h}$ (caspase-3) or $72 \mathrm{~h}$ (caspases-7 and -9 ) after treatment with $40 \mathrm{ng} / \mathrm{ml} \mathrm{TNF}-\alpha$ and $20 \mathrm{~Gy}$ irradiation. The Western blots show only activated caspases as designated on the right

sensitizing cells to death complex formation. ${ }^{49}$ However, even though irradiation and TNF- $\alpha$ both increase expression of FAS on the surface of LNCaP cells, ${ }^{25}$ we did not detect sensitization of $\mathrm{LNCaP}$ cells to $\mathrm{CH}-11$-induced apoptosis by $\mathrm{C}_{2}$ ceramide, consistent with the notion that sensitization to the proapoptotic effects of ceramide on LNCaP cells affected the intrinsic cell death pathway.

We have also considered that ceramide responsiveness could have been activated by different degrees of signaling downstream from caspase-8. Both TNF- $\alpha$ and FAS activate caspase- 8 by mechanisms that are qualitatively different. ${ }^{33}$ Importantly, LNCaP cell death induced by $\mathrm{CH}-11$ and irradiation can be inhibited by the caspase- 8 inhibitor IETD, but not LNCaP cell death induced by TNF- $\alpha$ plus irradiation ${ }^{25}$ (our unpublished observations). Therefore, apoptosis pathways downstream from caspase- 8 are likely to be differentially activated by TNF- $\alpha$ and $\mathrm{CH}-11$ in LNCaP cells.

$\mathrm{CH}-11$ together with irradiation induced caspases-8, -3 , and DFF-45 activation. In contrast, TNF- $\alpha$ plus irradiation induced activation of caspases- 9 and -7 and BAX cleavage. These disparate apoptotic pathways are reminiscent to the type 1 and type 2 pathways of FAS-induced apoptosis proposed by Scaffidi. ${ }^{50}$ Type 1 cells undergo apoptosis by activation of caspase- 8 followed by activation of caspase- 3 and this is not blocked by ectopic expression of $\mathrm{Bcl}-2$ or $\mathrm{Bcl}-\mathrm{X}_{\mathrm{L}}$. In type 2 cells, there is diminished formation of the DISC and apoptosis is mediated by BAX-induced mitochondrial egress of cytochrome $c$ and activation of caspase-9. $C_{2}$-ceramide induced apoptosis only in the type 2 cells such as CEM and Jurkat, whereas $\mathrm{C}_{2}$-ceramide was inactive in type 1 cells, such as SKW6.4 and $\mathrm{H}_{9} .^{51}$ In the case of LNCaP cells, we have observed activation of type 1 or type 2 apoptosis depending on exposure of irradiated cells to $\mathrm{CH}-11$ or TNF- $\alpha$, respectively.

The analogy with Scaffidi's findings is limited by the relative resistance of $\mathrm{LNCaP}$ cells to induction of cell death and the importance of serine proteases in the mediation of some of 
the apoptotic effects of TNF- $\alpha$. In LNCaP cells there was also preferential activation of caspase- 7 by TNF- $\alpha$ plus irradiation and of caspase- 3 by $\mathrm{CH}-11$ plus irradiation. We and others have previously observed that caspase-7 is activated in LNCaP cells by a variety of proapoptotic agonists. ${ }^{32,40}$ In type 2 CEM and Jurkat cells, caspase- 9 and cleavage apoptosis was accompanied by activation of both caspases-7 and $-3 .^{50}$ Since caspase- 3 is activated within $24 \mathrm{~h}$ of LNCaP cell exposure to TNF- $\alpha$ and cycloheximide, it is likely that LNCaP cells express a protein that limits caspase- 3 activation. ${ }^{52}$ The influence of cell type on choice of apoptosis pathways is further illustrated by experiments with $\mathrm{C}_{2}$-ceramide and FAS treatment of glioma cells that led to cleavage of caspases-3, 8 , and -9 and cytochrome $c$ release. ${ }^{53}$ Therefore, in the proper cellular milieu, FAS can activate mitochondrial apoptosis pathways and can interact with ceramide. Of note is that ceramide-induced activation of the intrinsic mitochondrialdependent pathway in LNCaP cells whereas there was no activation of the extrinsic pathway. This is in contrast to many reports that ceramide production can both activate and be activated by the extrinsic apoptosis pathway. ${ }^{54-57}$ Once again, we believe that differences between our findings and other cell systems are explained by differences in cellular milieu.

Ceramide-induced LNCaP cell death was caspase-independent since it was not blocked by the pancaspase inhibitor z-VAD. Ceramide has been shown to induce caspasedependent cell death in many systems, but can also induce necrotic glioma cell death that can be blocked by an AKTdependent survival signal. ${ }^{58}$ In glioma cells, ceramide failed even to induce mitochondrial depolarization. In contrast, both ceramide and its metabolite GD3 have generally been shown to induce mitochondrial depolarization. ${ }^{59,60}$ Activation of mitochondria was likely mediated by BAX, as it was cleaved after exposure of cells to TNF- $\alpha$ and irradiation. BAX can also be a target for a variety of proteases. We did not determine whether serine proteases, caspase-8, or some other caspase was responsible for $\mathrm{BAX}$ cleavage in $\mathrm{LNCaP}$ cells, although $\mathrm{BAX}$ has been reported not to be a target of caspase-3. ${ }^{61}$ Ceramide has also been shown to cause clumping of CD95 on the cell surface ${ }^{62,63}$ CD95 aggregation facilitates death signaling. We did not observe any effect of ceramide on cell death mediated by FAS after $\mathrm{CH}-11$ exposure. In LNCaP cells ceramide had a profound effect on apoptosis induced by TNF$\alpha$ and irradiation. Our data imply that the major effect of ceramide on the effect of death ligands was via the intrinsic mitochondrial pathway and caspase- 9 activation and not by any effect on death receptors that should have been manifested through the activation of caspases-8 and -3 .

This study has demonstrated that serine protease activation is integral to LNCaP cell death induction by TNF- $\alpha$ and irradiation. A proapoptotic serine protease Omi/HtrA2 has recently been found to be released from mitochondria as a result of a number of apoptotic stimuli. ${ }^{64-66}$ One target of Omi/ $\mathrm{HtrA2}$ is XIAP, an antiapoptotic protein that is sequestered by Smac, a mitochondrial proapoptotic protein. ${ }^{67-72}$ In LNCaP cells, microinjection of either cytochrome $c$ or Smac alone are insufficient to induce substantial apoptosis, but combined, the two are proapoptotic. ${ }^{73}$ Our data imply that serine protease activation is upstream from caspase-9 activation in LNCaP cells and therefore may have been responsible for apoptosis mediated by cytochrome $c$ and Smac egress from the mitochondria.

We have observed that stable expression of $I_{\kappa} B S R$ is antiapoptotic in LNCaP cells. ${ }^{25}$ This is in contrast to findings of others that $I_{\kappa} \mathrm{BSR}$ sensitizes cells to TNF- $\alpha$ induction of apoptosis. ${ }^{74}$ Differences in the effects of $\mid \kappa B S R$ may be because of differences in levels of $N F-\kappa B$ activity in the transfected cells or because of differences between laboratory strains of LNCaP cells. Our use of LNCaP $\left(\left.\right|_{\kappa} B S R\right)$ cells in this study was solely for the purpose of exploiting cell lines that have been shown to have attenuated activation of intrinsic apoptosis pathways after exposure to TNF- $\alpha \pm \gamma$-irradiation.

\section{Materials and Methods}

\section{Cell culture and cell death induction}

Culture of LNCaP cells and induction and assay of apoptosis with TNF- $\alpha$, $\mathrm{CH}-11$, and irradiation has been previously described. ${ }^{32-34}$ LNCaP cells were used at early passages starting at passage 20 from a large frozen stock maintained in our laboratory for more than a decade. Generally, $\mathrm{LNCaP}$ parental cells were used prior to passage 50 . Derivative LNCaPtransfected cells were used after confirmation that their properties were stable. Toward this end, all experiments were performed a minimum of three times. For experiments that required addition of either $\mathrm{C}_{2}$-ceramide or bacterial sphingomyelinase, the medium was changed from modified IMEM containing $5 \%$ FCS to modified IMEM without serum $24 \mathrm{~h}$ before treatment with death ligands and/or radiation. LNCaP cells stably transfected with FADD-DN and $I_{\kappa} \mathrm{BSR}$ have been previously described. $^{25,33}$

\section{Measurement of ceramide and sphingosine}

Assays for cellular levels of the sphingolipid metabolites ceramide and sphingosine have been previously described. ${ }^{32,35}$ Lipids were separated by thin-layer chromatography and the radioactive bands were quantitated using a Molecular Dynamics phosphorimage analyzer (Sunnyvale, CA, USA). The amount of ceramide content in each sample was standardized based upon the amount of phospholipids determined by standard methods. $^{75}$

Experiments were performed three times.

\section{Western blotting}

Blotting and antibodies used in these experiments have been previously described. ${ }^{34}$

\section{Measurement of mitochondrial membrane depolarization}

Assay of mitochondrial membrane depolarization and calculation of $\Delta \Psi_{\mathrm{m}}$ has been previously described. ${ }^{34}$ The assay was performed by using the DePsipher kit (Trevigen, Gaithersburg, MD, USA) ${ }^{76}$ Briefly, the cells were collected and washed with PBS(-), and suspended in DePsipher (JC-1,

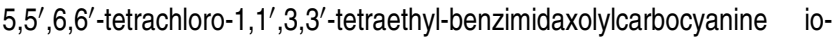
dide) solution (final concentration $5 \mu \mathrm{g} / \mathrm{ml}$ ). After incubation at $37^{\circ} \mathrm{C}$ for $20 \mathrm{~min}$, the samples were washed with PBS $(-)$ twice and analyzed at $488 \mathrm{~nm}$ argon laser by flow cytometry (FACStar plus, Beckton Dickinson, San Diego, CA, USA). 


\section{Acknowledgments}

This work was supported by Public Health Service Grant CA79912 to EP Gelmann and CA61774 to S Spiegel.

\section{References}

1. Chinnaiyan AM, Tepper CG, Seldin MF, O'Rourke K, Kischkel FC, Hellbardt S, Krammer PH, Peter ME and Dixit VM (1996) FADD/MORT1 is a common mediator of CD95 (Fas/APO-1) and tumor necrosis factor receptor-induced apoptosis. J. Biol. Chem. 271: 4961-4965.

2. Chinnaiyan AM, O'Rourke K, Tewari M and Dixit VM (1995) FADD, a novel death domain-containing protein, interacts with the death domain of Fas and initiates apoptosis. Cell 81: 505-512.

3. Scaffidi C, Krammer PH and Peter ME (1999) Isolation and analysis of components of CD95 (APO-1/Fas) death-inducing signaling complex. Methods 17: $287-291$

4. Liu X, Zou H, Slaughter $C$ and Wang X (1997) DFF, a heterodimeric protein that functions downstream of caspase-3 to trigger DNA fragmentation during apoptosis. Cell 89: 175-184.

5. Scaffidi C, Medema JP, Krammer PH and Peter ME (1997) FLICE is predominantly expressed as two functionally active isoforms, caspase-8/a and caspase-8/b. J. Biol. Chem. 272: 26 953-26958.

6. Chinnaiyan AM, Orth K, O'Rourke K, Duan H, Poirier GG and Dixit VM (1996) Molecular ordering of the cell death pathway. J. Biol. Chem. 271: 4573-4576.

7. Duan H, Chinnaiyan AM, Hudson PL, Wing JP, He WW and Dixit VM (1996) ICE-LAP3, a novel mammalian homologue of the Caenorhabditis elegans cell death protein Ced-3 is activated during Fas- and tumor necrosis factor-induced apoptosis. J. Biol. Chem. 271: 1621-1625.

8. Tewari M, Quan LT, O'Rourke K, Desnoyers S, Zeng Z, Beidler DR, Poirier GG, Salvesen GS and Dixit VM (1995) Yama/CPP32 beta, a mammalian homolog of CED-3, is a CrmA-inhibitable protease that cleaves the death substrate poly(ADP-ribose) polymerase. Cell 81: 801-809.

9. Hsu H, Shu HB, Pan MG and Goeddel DV (1996) TRADD-TRAF2 and TRADDFADD interactions define two distinct TNF receptor 1 signal transduction pathways. Cell 84: 299-308.

10. Rath PC and Aggarwal BB (1999) TNF-induced signaling in apoptosis. J. Clin. Immunol. 19: 350-364.

11. Liu ZG, Hsu H, Goeddel DV and Karin M (1996) Dissection of TNF receptor 1 effector functions: JNK activation is not linked to apoptosis while NF-kappaB activation prevents cell death. Cell 87: 565-576.

12. Van Antwerp DJ, Martin SJ, Kafri T, Green DR and Verma IM (1996 Suppression of TNF-alpha-induced apoptosis by NF-kappaB. Science 274 : $787-789$.

13. Xu Y, Bialik S, Jones BE, limuro Y, Kitsis RN, Srinivasan A, Brenner DA and Czaja MJ (1998) NF-kappaB inactivation converts a hepatocyte cell line TNFalpha response from proliferation to apoptosis. Am. J. Physiol. 275: C1058C1066.

14. Beg AA and Baltimore D (1996) An essential role for NF-kappaB in preventing TNF-alpha-induced cell death. Science 274: 782-784.

15. Rodriguez $J$ and Lazebnik $Y$ (1999) Caspase-9 and APAF-1 form an active holoenzyme. Genes Dev. 13: 3179-3184.

16. Zhou P, Chou J, Olea RS, Yuan J and Wagner G (1999) Solution structure of Apaf-1 CARD and its interaction with caspase-9 CARD: a structural basis for specific adaptor/caspase interaction. Proc. Natl. Acad. Sci. USA 96: 1126511270.

17. Desagher S, Osen-Sand A, Nichols A, Eskes R, Montessuit S, Lauper S, Maundrell K, Antonsson B and Martinou JC (1999) Bid-induced conformational change of Bax is responsible for mitochondrial cytochrome $c$ release during apoptosis. J. Cell Biol. 144: 891-901.

18. Eskes R, Desagher S, Antonsson B and Martinou JC (2000) Bid induces the oligomerization and insertion of Bax into the outer mitochondrial membrane. Mol. Cell. Biol. 20: 929-935

19. Gross A, Yin XM, Wang K, Wei MC, Jockel J, Milliman C, Erdjument-Bromage H, Tempst P and Korsmeyer SJ (1999) Caspase cleaved BID targets mitochondria and is required for cytochrome $c$ release, while $B C L-X L$ prevents this release but not tumor necrosis factor-R1/Fas death. J. Biol. Chem. 274: 1156-1163.

20. Li H, Zhu H, Xu CJ and Yuan J (1998) Cleavage of BID by caspase 8 mediates the mitochondrial damage in the Fas pathway of apoptosis. Cell 94: 491-501.

21. Luo X, Budihardjo I, Zou H, Slaughter C and Wang X (1998) Bid, a Bcl2 interacting protein, mediates cytochrome $c$ release from mitochondria in response to activation of cell surface death receptors. Cell 94: 481-490.

22. Hedlund TE, Meech SJ, Srikanth S, Kraft AS, Miller GJ, Schaack JB and Duke RC (1999) Adenovirus-mediated expression of Fas ligand induces apoptosis of human prostate cancer cells. Cell Death Differ. 6: 175-182.

23. Kasibhatla S, Brunner T, Genestier L, Echeverri F, Mahboubi A and Green DR (1998) DNA damaging agents induce expression of Fas ligand and subsequent apoptosis in T lymphocytes via the activation of NF-kappaB and AP-1. Mol. Cell. 1: 543-551.

24. Teixeiro E, Garcia-Sahuquillo A, Alarcon B and Bragado R (1999) Apoptosisresistant $T$ cells have a deficiency in NF-kappaB-mediated induction of Fas ligand transcription. Eur. J. Immunol. 29: 745-754.

25. Kimura K and Gelmann EP (2002) Propapoptotic effects of NF- $\kappa$ B in LNCaP prostate cancer cells lead to serine protease activation. Cell Death Differ. 9: $972-980$.

26. Hannun YA and Obeid LM (1997) Ceramide and the eukaryotic stress response. Biochem. Soc. Trans. 25: 1171-1175.

27. Kolesnick RN and Kronke M (1998) Regulation of ceramide production and apoptosis. Annu. Rev. Physiol. 60: 643-665.

28. Bose R, Verheij M, Haimovitz-Friedman A, Scotto K, Fuks Z and Kolesnick R (1995) Ceramide synthase mediates daunorubicin-induced apoptosis: an alternative mechanism for generating death signals. Cell 82: 405-414.

29. Kolesnick RN, Haimovitz-Friedman A and Fuks Z (1994) The sphingomyelin signal transduction pathway mediates apoptosis for tumor necrosis factor, Fas, and ionizing radiation. Biochem. Cell Biol. 72: 471-474.

30. Santana P, Pena LA, Haimovitz-Friedman A, Martin S, Green D, McLoughlin M, Cordon-Cardo C, Schuchman EH, Fuks Z and Kolesnick R (1996) Acid sphingomyelinase-deficient human lymphoblasts and mice are defective in radiation-induced apoptosis. Cell 86: 189-199.

31. Pena LA, Fuks $Z$ and Kolesnick RN (2000) Radiation-induced apoptosis of endothelial cells in the murine central nervous system: protection by fibroblast growth factor and sphingomyelinase deficiency. Cancer Res. 60: 321-327.

32. Kimura K, Bowen C, Spiegel S and Gelmann EP (1999) Tumor necrosis factoralpha sensitizes prostate cancer cells to gamma-irradiation-induced apoptosis. Cancer Res. 59: 1606-1614.

33. Kimura K and Gelmann EP (2000) Tumor necrosis factor-alpha and Fas activate complementary Fas-associated death domain-dependent pathways that enhance apoptosis induced by gamma-irradiation. J. Biol. Chem. 275: 8610-8617.

34. Kimura K, Markowski M, Bowen C and Gelmann EP (2001) Androgen blocks apoptosis of hormone-dependent prostate cancer cells. Cancer Res. 61: 56115618.

35. Nava VE, Cuvillier O, Edsall LC, Kimura K, Milstien S, Gelmann EP and Spiegel $S$ (2000) Sphingosine enhances apoptosis of radiation-resistant prostate cancer cells. Cancer Res. 60: 4468-4474.

36. Dbaibo GS, Perry DK, Gamard CJ, Platt R, Poirier GG, Obeid LM and Hannun YA (1997) Cytokine response modifier A (CrmA) inhibits ceramide formation in response to tumor necrosis factor (TNF)-alpha: CrmA and Bcl-2 target distinct components in the apoptotic pathway. J. Exp. Med. 185: 481-490.

37. Smyth MJ, Perry DK, Zhang J, Poirier GG, Hannun YA and Obeid LM (1996) prICE: a downstream target for ceramide-induced apoptosis and for the inhibitory action of Bcl-2. Biochem. J. 316 (Part 1): 25-28.

38. Orth K, O'Rourke K, Salvesen GS and Dixit VM (1996) Molecular ordering of apoptotic mammalian CED-3/ICE-like proteases. J. Biol. Chem. 271: 2097720980.

39. Salvesan GS and Dixit VM (1997) Caspases: intracellular signaling by proteolysis. Cell 91: 443-446.

40. Marcelli M, Cunningham GR, Haidacher SJ, Padayatty SJ, Sturgis L, Kagan C and Denner L (1998) Caspase-7 is activated during lovastatin-induced apoptosis of the prostate cancer cell line LNCaP. Cancer Res 58: 76-83.

41. Lee SJ, Dimtchev A, Lavin MF, Dritschilo A and Jung M (1998) A novel ionizing radiation-induced signaling pathway that activates the transcription factor NFkappaB. Oncogene 17: 1821-1826. 
42. Jung M, Zhang Y, Dimtchev A and Dritschilo A (1998) Impaired regulation of nuclear factor-kappaB results in apoptosis induced by gamma radiation. Radiat. Res. 149: 596-601.

43. Brenner B, Ferlinz K, Grassme H, Weller M, Koppenhoefer U, Dichgans J, Sandhoff K, Lang F and Gulbins E (1998) Fas/CD95/Apo-I activates the acidic sphingomyelinase via caspases. Cell Death Differ. 5: 29-37.

44. Cifone MG, De Maria R, Roncaioli P, Rippo MR, Azuma M, Lanier LL, Santoni A and Testi R (1994) Apoptotic signaling through CD95 (Fas/Apo-1) activates an acidic sphingomyelinase. J. Exp. Med. 180: 1547-1552

45. Gamen S, Marzo I, Anel A, Pineiro A and Naval J (1996) CPP32 inhibition prevents Fas-induced ceramide generation and apoptosis in human cells. FEBS Lett. 390: 232-237.

46. Ghafourifar P, Klein SD, Schucht O, Schenk U, Pruschy M, Rocha S and Richter C (1999) Ceramide induces cytochrome $c$ release from isolated mitochondria. Importance of mitochondrial redox state. J. Biol. Chem. 274: 6080-6084.

47. Richter $C$ and Ghafourifar $P$ (1999) Ceramide induces cytochrome $c$ release from isolated mitochondria. Biochem. Soc. Symp. 66: 27-31.

48. Wieder T, Geilen CC, Kolter T, Sadeghlar F, Sandhoff K, Brossmer R, Ihrig P, Perry D, Orfanos CE and Hannun YA (1997) Bcl-2 antagonizes apoptotic cell death induced by two new ceramide analogues. FEBS Lett. 411: 260-264.

49. Cremesti A, Paris F, Grassme H, Holler N, Tschopp J, Fuks Z, Gulbins E and Kolesnick R (2001) Ceramide enables fas to cap and kill. J. Biol. Chem. 276: 23954-23961.

50. Scaffidi C, Fulda S, Srinivasan A, Friesen C, Li F, Tomaselli KJ, Debatin KM, Krammer PH and Peter ME (1998) Two CD95 (APO-1/Fas) signaling pathways. EMBO J. 17: 1675-1687.

51. Scaffidi C, Schmitz I, Zha J, Korsmeyer SJ, Krammer PH and Peter ME (1999) Differential modulation of apoptosis sensitivity in CD95 type I and type II cells. J. Biol. Chem. 274: 22 532-22 538.

52. Kulik G, Carson JP, Vomastek T, Overman K, Gooch BD, Srinivasula S, Alnemri E, Nunez $G$ and Weber MJ (2001) Tumor necrosis factor alpha induces BID cleavage and bypasses antiapoptotic signals in prostate cancer LNCaP cells. Cancer Res. 61: 2713-2719.

53. Wagenknecht B, Roth W, Gulbins E, Wolburg H and Weller M (2001) C2ceramide signaling in glioma cells: synergistic enhancement of CD95mediated, caspase-dependent apoptosis. Cell Death Differ. 8: 595-602.

54. Hannun YA and Obeid LM (1997) Mechanisms of ceramide-mediated apoptosis. Adv. Exp. Med. Biol. 407: 145-149.

55. Juo P, Woo MS, Kuo CJ, Signorelli P, Biemann HP, Hannun YA and Blenis J (1999) FADD is required for multiple signaling events downstream of the receptor Fas. Cell Growth Differ. 10: 797-804.

56. Sweeney EA, Inokuchi J and Igarashi Y (1998) Inhibition of sphingolipid induced apoptosis by caspase inhibitors indicates that sphingosine acts in an earlier part of the apoptotic pathway than ceramide. FEBS Lett. 425: 61-65.

57. Tepper AD, de Vries E, van Blitterswijk WJ and Borst J (1999) Ordering of ceramide formation, caspase activation, and mitochondrial changes during. J. Clin. Invest. 103: 971-978

58. Mochizuki T, Asai A, Saito N, Tanaka S, Katagiri $H$, Asano T, Nakane M, Tamura A, Kuchino Y, Kitanaka C and Kirino T (2002) Akt protein kinase inhibits non-apoptotic programmed cell death induced by ceramide. J. Biol. Chem. 277: 2790-2797.

59. Rippo MR, Malisan F, Ravagnan L, Tomassini B, Condo I, Costantini P, Susin SA, Rufini A, Todaro M, Kroemer G and Testi R (2000) GD3 ganglioside as an intracellular mediator of apoptosis. Eur. Cytokine Netw. 11: 487-488.

60. Rippo MR, Malisan F, Ravagnan L, Tomassini B, Condo I, Costantini P, Susin SA, Rufini A, Todaro M, Kroemer G and Testi R (2000) GD3 ganglioside directly targets mitochondria in a bcl-2-controlled fashion. FASEB J. 14: 2047-2054.
61. Kirsch DG, Doseff A, Chau BN, Lim DS, Souza-Pinto NC, Hansford R Kastan MB, Lazebnik YA and Hardwick JM (1999) Caspase-3-dependent cleavage of Bcl-2 promotes release of cytochrome c. J. Biol. Chem. 274: $21155-21161$.

62. Grassme H, Schwarz H and Gulbins E (2001) Molecular mechanisms of ceramide-mediated CD95 clustering. Biochem. Biophys. Res. Commun. 284 1016-1030.

63. Grassme H, Jekle A, Riehle A, Schwarz H, Berger J, Sandhoff K, Kolesnick R and Gulbins E (2001) CD95 signaling via ceramide-rich membrane rafts. J. Biol. Chem. 276: 20 589-20596.

64. Gray CW, Ward RV, Karran E, Turconi S, Rowles A, Viglienghi D, Southan C Barton A, Fantom KG, West A, Savopoulos J, Hassan NJ, Clinkenbeard H, Hanning C, Amegadzie B, Davis JB, Dingwall C, Livi GP and Creasy CL (2000) Characterization of human $\mathrm{HtrA2}$, a novel serine protease involved in the mammalian cellular stress response. Eur. J. Biochem. 267: 5699-5710.

65. Hegde R, Srinivasula SM, Zhang Z, Wassell R, Mukattash R, Cilenti L, DuBois G, Lazebnik Y, Zervos AS, Fernandes-Alnemri T and Alnemri ES (2002) Identification of Omi/HtrA2 as a mitochondrial apoptotic serine protease that disrupts inhibitor of apoptosis protein-caspase interaction. J. Biol. Chem. 277: 432-438.

66. Savopoulos JW, Carter PS, Turconi S, Pettman GR, Karran EH, Gray CW, Ward RV, Jenkins $O$ and Creasy CL (2000) Expression, purification, and functional analysis of the human serine protease HtrA2. Protein Expr. Purif. 19: 227-234.

67. Martins LM, laccarino I, Tenev T, Gschmeissner S, Totty NF, Lemoine NR, Savopoulos J, Gray CW, Creasy CL, Dingwall C and Downward J (2002) The serine protease Omi/HtrA2 regulates apoptosis by binding XIAP through a reaper-like motif. J. Biol. Chem. 277: 439-444.

68. Suzuki Y, Imai Y, Nakayama H, Takahashi K, Takio K and Takahashi R (2001) A serine protease, HtrA2, is released from the mitochondria and interacts with XIAP, inducing cell death. Mol. Cell 8: 613-621.

69. van Loo G, van Gurp M, Depuydt B, Srinivasula SM, Rodriguez I, Alnemri ES, Gevaert K, Vandekerckhove J, Declercq W and Vandenabeele P (2002) The serine protease Omi/HtrA2 is released from mitochondria during apoptosis. Omi interacts with caspase-inhibitor XIAP and induces enhanced caspase activity. Cell Death Differ. 9: 20-26.

70. Verhagen AM, Silke J, Ekert PG, Pakusch M, Kaufmann H, Connolly LM, Day CL, Tikoo A, Burke R, Wrobel C, Moritz RL, Simpson RJ and Vaux DL (2002) HtrA2 promotes cell death through its serine protease activity and its ability to antagonize inhibitor of apoptosis proteins. J. Biol. Chem. 277: 445-454.

71. Srinivasula SM, Datta $P$, Fan XJ, Fernandes-Alnemri T, Huang $Z$ and Alnemri ES (2000) Molecular determinants of the caspase-promoting activity of Smac/ DIABLO and its role in the death receptor pathway. J. Biol. Chem. 275: 36 15236157.

72. Wu G, Chai J, Suber TL, Wu JW, Du C, Wang X and Shi Y (2000) Structural basis of IAP recognition by Smac/DIABLO. Nature 408: 1008-1012.

73. Carson JP, Behnam M, Sutton JN, Du C, Wang X, Hunt DF, Weber MJ and Kulik G (2002) Smac is required for cytochrome $c$-induced apoptosis in prostate cancer LNCaP cells. Cancer Res. 62: 18-23.

74. Muenchen HJ, Lin DL, Walsh MA, Keller ET and Pienta KJ (2000) Tumor necrosis factor-alpha-induced apoptosis in prostate cancer cells through inhibition of nuclear factor-kappaB by an IkappaBalpha 'super-repressor'. Clin. Cancer Res. 6: 1969-1977.

75. Van Veldhoven PP and Mannaerts GP (1987) Inorganic and organic phosphate measurements in the nanomolar range. Anal. Biochem. 161: 45-48.

76. Reers M, Smiley ST, Mottola-Hartshorn C, Chen A, Lin M and Chen LB (1995) Mitochondrial membrane potential monitored by JC-1 dye. Methods Enzymol. 260: 406-417. 